\title{
Barriers and Facilitators to HIV Prevention Interventions for Reducing Risky Sexual Behavior Among Youth Worldwide: A Systematic Review
}

\author{
Fungai Mbengo ( $\nabla$ fmbengo@our.ecu.edu.au ) \\ School of Nursing and Midwifery, Edith Cowan University \\ Esther Adama \\ School of Nursing and Midwifery, Edith Cowan University \\ Amanda Towell-Barnard \\ School of Nursing and Midwifery, Edith Cowan University \\ Arvin Bhana \\ Health Systems Research Unit, SAMRC
}

\section{Research Article}

Keywords: Barriers, facilitators, HIV prevention intervention, risky sexual behavior, youth, systematic review

Posted Date: December 10th, 2021

DOI: https://doi.org/10.21203/rs.3.rs-1125426/v1

License: (c) (i) This work is licensed under a Creative Commons Attribution 4.0 International License. Read Full License 


\section{Abstract}

Background: Interventions aimed at reducing risky sexual behavior is considered an important strategy for averting Human Immunodeficiency Virus (HIV) among youth (15-24 years) who continue to be vulnerable to the disease. Enhancing intervention success requires a comprehensive understanding of the barriers and facilitators to interventions targeting youth. However, there is lack of a systematic review of both quantitative and qualitative studies to comprehensively identity and synthesize barriers and facilitators to HIV prevention interventions for reducing risky sexual behavior among youth worldwide. This review aimed to identify and synthesize barriers and facilitators to HIV prevention interventions for reducing risky sexual behavior among youth globally based on original peer-reviewed studies published in the last decade.

Methods: The Joanna Briggs Institute approach for mixed methods systematic reviews and Preferred Reporting Items for Systematic Reviews and Meta-Analysis guidelines were used to guide this review. Seven electronic databases, Cambridge and Oxford journals, Joint United Nations Programme on HIV/AIDS and World Health Organization websites, and reference lists of included studies were searched for eligible articles. Studies that met the inclusion criteria underwent quality appraisal and data extraction. Findings were analyzed using thematic synthesis and underpinned by the Determinant Framework.

Results: Overall, eight qualitative studies, four quantitative studies and one mixed methods study were included in the review. Several barriers and facilitators across the five Determinant Framework domains were identified. Most of the barriers fell under the characteristics of the context domain (e.g., gender-biased norms). The next important group of barriers emerged within the characteristics of the end users domain (e.g., fear of relationship breakdown). In terms of facilitators, the majority fell under the characteristics of the context domain (e.g., financial support from family) and characteristics of the end users domain (e.g., fear of pregnancy and sexually transmitted infections). The next common set of facilitators appeared within the characteristics of the strategy of facilitating implementation domain (e.g., implementation of intervention with fidelity).

Conclusion: This review identified several multi-level barriers and facilitators to HIV prevention interventions for reducing risky sexual behavior among youth. Multi-level and combination approaches are needed to address these factors and enhance intervention success.

\section{Background}

Young people continue to be at considerable risk for Human Immunodeficiency Virus (HIV) despite intervention efforts to control the disease [1]. Specifically, youth aged between 15 and 24 account for nearly $30 \%$ of all new HIV infections and $9 \%$ of all people living with HIV worldwide [2]. Moreover, there are indications that HIV infection rates among youth will increase annually by $13 \%$ leading to approximately 3.5 million new infections by 2030 [2, 3]. The socio-ecological model [4, 5] suggests that young people are vulnerable to HIV due to numerous factors at different socio-ecological levels that affect risky sexual behaviors including low self-esteem, lack of parent-child communication, peer pressure, poverty [6, 7], alcohol or drug abuse [8], limited HIV-related knowledge, gender-based violence [9], gender disparities and cultural factors [10, 11].

To date HIV has no cure, therefore HIV prevention programs aimed at reducing risky sexual behavior are regarded as an important strategy of controlling the disease. As a result, various HIV prevention interventions have been developed for youth aiming to reduce the risk of HIV infection $[12,13]$. Reviews that have evaluated the efficacy of HIV prevention interventions for reducing risky sexual behavior among youth suggest that such interventions are more effective at changing non-behavioral outcomes (e.g., attitudes, beliefs, intentions and HIV-related knowledge), and less effective at changing behavioral outcomes (e.g., condom use) [14-16].

Developing effective strategies to enhance intervention efficacy requires a comprehensive understanding of the barriers and facilitators to HIV prevention interventions targeting youth. Theoretical framework is valuable for identifying barriers and facilitators to an intervention and for developing policies and strategies to promote intervention success [17, 18]. One such theoretical framework is the Determinant Framework [17]. This framework is composed of five major domains or levels, which can capture a myriad of factors that affect the success of an intervention. These domains include: (i) characteristics of the implementation object, which involves features of an intervention that might influence intervention success (e.g., duration of the intervention); (ii) characteristics of the users or adopters, which includes features of implementers of an intervention that might influence intervention success (e.g., training of the implementers); (iii) characteristics of the end users, which includes attributes of recipients of an intervention that might affect intervention success (e.g., age, knowledge and self-efficacy of the youth receiving the intervention); (iv) characteristics of the context, which involves attributes of conditions or surroundings of an intervention that might affect intervention success (e.g., availability of funding or resources within the organization implementing the intervention); and (v) characteristics of the strategy of facilitating implementation, which includes tactics of delivering a program that might influence intervention success (e.g., implementation of intervention with fidelity or according to plan) [17].

In the last decade, a number of systematic reviews have been conducted on barriers and facilitators to HIV prevention interventions for reducing risky sexual behavior in youth [19-25]. However, these reviews have synthesized research findings from studies that were conducted using quantitative approaches [19-25]. Furthemore, these reviews have focused on studies conducted in a specific geographical region; for instance, subSaharan Africa [22-24], developing countries [20], Europe [21], and South Africa [19, 25]. Other reviews have focused on barriers [22] or facilitators [20] only. Moreover, in the last decade, no systematic review has included both quantitative and qualitative studies to identity and synthesize barriers and facilitators to HIV prevention interventions for reducing risky sexual behavior among youth worldwide. Therefore, the purpose of this review was

Page $2 / 18$ 
to synthesize current global evidence on barriers and facilitators to HIV prevention interventions for reducing risky sexual behavior among youth based on peer-reviewed quantitative, qualitative or mixed methods studies published in the last decade. This is expected to provide holistic evidence to support youth HIV prevention programs across the globe. Consistent with other reviews, barriers were defined as factors that impede intervention success (e.g., lack of funding) [23]. Facilitators were defined as factors that promote intervention success (e.g., availability of funding) [23].

\section{Methods}

\section{Study design}

This systematic review was conducted using the Joanna Briggs Institute (JBI) approach for mixed methods systematic reviews [26] and the Preferred Reporting Items for Systematic Reviews and Meta-Analysis (PRISMA) guidelines [27]. The mixed methods approach was employed to obtain a comprehensive synthesis of evidence than that provided by a single method approach [28]. The protocol for this review was registered in PROSPERO (registration number CRD42020187272) [29].

\section{Inclusion criteria}

Studies were included in this review if they were:

a. original peer-reviewed studies published in English language;

b. focused on youth (15-24 years);

c. examined barriers and facilitators to HIV prevention intervention for reducing risky sexual behavior;

d. conducted in any geographical location;

e. conducted in educational settings (e.g., schools), community settings (e.g., rural areas) or healthcare settings (e.g., clinics);

f. conducted using quantitative, qualitative or mixed methods study designs;

g. published between January 2010 and May 2020. This period was chosen to obtain current evidence.

\section{Search strategy}

The CINAHL, Cochrane Library, Google Scholar, MEDLINE, PsychINFO, ProQuest Central and Web of Science datababes, Cambridge and Oxford journals, Joint United Nations Programme on HIV/AIDS (UNAIDS) and World Health Organization (WHO) websites were searched for eligible studies using relevant keywords. Moreover, reference lists of included studies were screened to identify additional eligible studies. Keywords used to conduct the search included "Youth”, “Barriers”, “Facilitators”, “HIV Prevention Intervention”, “Risky Sexual Behavior”, “Efficacy” and "Implementation” (Supplementary File 1 Table 1). Booleans (e.g., "OR" and "AND”) were used to combine similar and different search terms, respectively. For example, (youth OR young people OR teen OR young adults OR students OR adolescents) AND (barriers OR challenges OR constrains OR difficulties OR obstacles OR issues OR problems).

\section{Study selection}

Following the search, all identified citations were collated and uploaded into EndNote X9 Reference Management System and duplicates removed. FM, EA and ATB assessed the title, abstract and full text articles against the inclusion criteria. Any disagreements were resolved through consensus.

\section{Assessment of methodological quality}

The methodological quality of the studies were assessed independently by FM, EA and ATB, and differences were resolved through discussion. Authors of papers were contacted to request for missing information. Quantitative studies were assessed using the JBI Critical Appraisal Checklist for Randomized Controlled Trials (13 items) [26] and JBI Critical Appraisal Checklist for Quasi-Experimental Studies (nine items) [26]. The JBI Critical Appraisal Checklist for Qualitative Research (10 items) [26] was used to assess qualitative studies. Mixed-methods studies were appraised using both methods. A study was considered 'good' if it scored more than $70 \%$, 'fair' if it scored between 50\% and 70\% and 'poor' (excluded) if it scored less than $50 \%$ on quality appraisal tool.

\section{Data extraction}

FM extracted data from the included studies using a standardized JBI data extraction form [26]. Data extraction was discussed with EA, MTB and $A B$, and any discrepancies were resolved though consensus. Details extracted include: author, year of publication, title of the study, phenomena of interest, study location, setting, study design, population and sample size, methods, data analysis and findings (barriers and facilitators). Findings regarding barriers and facilitators were identified through repeated reading of the studies. Supplementary File 2, Tables 2-14 presents extracted findings relating to barriers and facilitators with each finding supported by an illustration from the same text that informed the finding. As recommended by JBI, quantitative data were converted into 'qualitized data' (textual descriptions or narrative interpretation of the quantitative findings) to enhance integration of quantitative data with qualitative data. 


\section{Data synthesis}

Synthesis involved two phases. In the first phase, a thematic synthesis approach was used [30, 31]. This involved reading of the findings several times to familiarize with the data, systematic coding of data and identification of prominent themes. In the second phase, barriers and facilitators obtained from thematic synthesis were mapped to the Determinant Framework [17] to highlight the key barriers and facilitators, and strategies needed within the different Determinant Framework levels to improve intervention success [17, 18]. Synthesis was undertaken by FM, and discussed with EA, MTB and AB. Any disagreements were resolved through consensus.

\section{Results}

\section{Search outcome}

Of the 7413 records identified, 6290 were screened based on title and abstract. Of these, full text of 144 studies were further screened. Thirteen (13) studies were deemed to meet the inclusion criteria. No studies were excluded following assessment of methodological quality (Fig. 1).

\section{Characteristics of the included studies}

The characteristics of the included studies are summarized in Table 1. Studies included in the review consisted of eight qualititative studies [32, 36$39,42-44]$, four quantitative studies [34, 35, 40,41] and one mixed methods study [33]. Of the quantitative studies, two studies were quasiexperimental studies without a comparison group [34,35], one study was a quasi-experimental study with a comparison group [40], and one study was a randomised controlled trial [41].

Included studies were published between 2010 and 2020, with six studies [34, 38, 41-44] published in 2012.

Seven countries were represented across the included studies including the United States of America [34, 35, 37, 40-42], Tanzania [43, 44], Yemen [32], Myanmar [33], South Africa [36], Uganda [38] and Mozambique [39].

In terms of setting, seven studies were conducted in community settings [32, 34-37, 39, 43], two studies were undertaken in educational settings [38, 40], two studies were conducted in healthcare settings [41, 42], one study was undertaken in community and healthcare setting [33], and one study was conducted in community, educational and healthcare setting [44].

Participants were youth or intervention receipients in eight studies [34-38, 41-43]. One study included youth and implementers [33], one study involved youth, implementers and community members [32], one study included youth, family members and community members [39], one study incorporated youth and community members [44], and one study included implementers [40]. The number of participants within the included studies ranged from two to 343. Rorhbach, 2019 [40] did not report the number of implementers (trained program staff).

Overall, the quality of the included studies was good with nine studies [32, 34, 35, 39-44] scoring more than $70 \%$ on quality appraisal tool. Four studies [33, 36-38] were rated as fair (scored between $50 \%$ and $70 \%$ on quality appraisal tool) [Supplementary File 1, Tables $2-4$ ].

\section{Barriers and facilitators}

Thematic synthesis [30,31] and mapping of the study findings to the Determinant Framework [17] highlighted a wide range of barriers and facilitators to HIV prevention interventions for reducing risky sexual behavior among youth. A summary of the identified barriers and facilitators across the five Determinant Framework domains is presented in Table 2.

\section{Barriers to HIV prevention interventions for reducing risky sexual behavior among youth}

A total of 79 barriers to HIV prevention interventions for reducing risky sexual behavior among youth were identified from the included studies: 42 in the characteristics of the context, 21 in the characteristics of the end users, seven in the characteristics of the implementation object, five in the characteristics of the strategy of facilitating implementation and four in the characteristics of the users domains.

\section{Characteristics of the context}

Barriers within the characteristics of the context domain were reported by 11 studies [32-34, 36-39, 41-44]. Four types barriers emerged: interpersonal, community, organizational or institutional and structural barriers.

The most common interpersonal barriers identified involved those linked to reduction of risky sexual behavior among youth. These included partner's refusal of HIV prevention methods (e.g., condom use) [32, 33, 38, 39, 42], negative peer influence [38, 43, 44], lack of financial support from family [38, 39, 43], partner's desire for pregnancy [42] and lack of child-parent communication on sexual issues [36, 38]. Additional interpersonal barrier reported included lack of support for critical thinking among young people [44]. 
Community barriers that occurred more prominently involved those associated with reduction of risky sexual behavior among youth. These included gender-biased norms [36-39, 43, 44], norms discouraging open communication on sexual issues, myths about contraceptive [32, 44], limited resources or services in the community (e.g., programs targeting young people) [32,33], cultural beliefs and norms encouraging risky sexual behaviors [44]. Another common set of community barriers identified consisted of those associated with young people's participation in the intervention, such as incarceration and community violence [34].

Reported organizational barriers included lack of financial and human resources, inaccessibility of healthcare facilities, limited confidentiality and restrictions on depicting of condoms in schools [44]. Other type of organizational barriers identified involved those linked to reduction of risky sexual behavior among youth, and these included lack of resources (e.g., personnel); inaccessibility of services (e.g., condoms) and limited confidentiality [44]. Additional organizational barriers reported comprised of those associated with youth's participation in the intervention. This included inaccessibility of intervention venue [34,37].

The most common set of structural barriers reported involved those correlated with reduction of risky behavior among young people, such as gender-based violence [39, 41], unemployment [32] and limited economic opportunities [44]. Additionally, poverty, limited demand and cost of services (e.g., condoms) [44] were identified as structural barriers.

\section{Characteristics of the end users}

Seven studies [32, 33, 38, 41-44] identified barriers at the level of characteristics of the end users. Barriers that appeared more prominently included those associated with reduction of risky sexual behavior among youth. Such barriers included lack of self-confidence [42], desire for pregnancy or children [42, 43], low perceptions of risk of sexually transmitted infections including HIV [38, 42-44], fear of relationship breakdown [33, 38, 42, 43] and poor decision-making skills $[42,44]$. Other common set of barriers consisted of those related to young people's participation in the intervention, such as concern for privacy [32] and fear of stigma [44]. Further barriers reported included being uncooperative, having low literacy and having limited sexual health knowledge [44].

\section{Characteristics of the implementation object}

Five studies [33-35, 43,44] mentioned barriers within the domain of the characteristics of the implementation object. The most common set of barriers identified involved those associated with intervention acceptability among young people. Such barriers included incompatibility of intervention content with the needs of youth [33-35, 43], long duration of the intervention [33, 35] and complexity of the intervention [35]. Additionally, barriers reported concerned those linked to youth's participation in the intervention, such as restricted days and times of the intervention [34] and age requirements that excluded other youth [33]. Additional barriers that emerged included those associated with reduction of risky sexual behavior among young people. This included limited intervention content [44]. Incompatibility of intervention content with needs of community members [44] was identified as a barrier to intervention acceptability among community members.

\section{Characteristics of the strategy of facilitating implementation}

Two studies $[32,44]$ mentioned barriers within the characteristics of the strategy of facilitating implementation domain. Barriers reported included failure to implement the intervention with fidelity, use of non-participatory facilitating or teaching methods, use of corporal punishment and sexual abuse [44]. Another category of barriers identified involved those associated intervention acceptability among youth. This included use of nonparticipatory facilitating methods [32].

\section{Characteristics of the users}

At the level of characteristics of the users, barriers were reported by two studies [37,44]. Identified barriers included implementers' lack of knowledge related to content of the intervention, poor education or training of implementers and implementers' lack of exemplary or positive behavior [44]. Adult or older implementers [37] was mentioned as a barrier to intervention acceptability among young people.

\section{Facilitators to HIV prevention interventions for reducing risky sexual behavior among youth}

There were 53 facilitators to HIV prevention interventions for reducing risky sexual behavior among youth identified from the included studies: 15 in the characteristics of the end users, 15 in the characteristics of the context, 14 in the characteristics of the strategy of facilitating implementation, five in the characteristics of the implementation object and four in the characteristics of the users domains

\section{Characteristics of the end users}

Facilitators within the characteristics of the end users domain were reported in seven studies [32, 36, 37, 39, 42-44]. Facilitators that emerged more prominently consisted of those related to reduction of risky sexual behavior among youth. Such facilitators included fear of pregnancy and sexually transmitted infections including HIV [32, 37, 43], having strong ambitions or being future-oriented [39, 44], having good problem-solving skills, having high self-confidence, being knowledgeable [42], having high self-motivation [39] and low socio-economic status (e.g., lack of money to pay 
for sex) [44]. Other group of facilitators identified comprised of those associated with young people's participation in the intervention. These included desire to acquire knowledge and need for enjoyment [37].

\section{Characteristics of the context}

Six studies [33, 38, 39, 42-44] identified facilitators at the characteristics of the context level. Three classifications of facilitators occurred: interpersonal, community and organizational facilitators.

The most common interpersonal facilitators reported involved those associated with reduction of risky sexual behavior among youth. These included partner's consent to use an HIV prevention method (e.g., condom use) [42, 43], positive peer influence, restrictive parenting [38, 44], financial support from family [39, 43] and teacher advice [38].

Similarly, community facilitators that emerged more prominently comprised of those linked to reduction of risky sexual behavior among young people. Such facilitators included norms encouraging healthy sexual practices (e.g., abstinence and delaying of sexual debut) [38, 44], norms encouraging discussion of sexual issues [44] and religious beliefs discouraging risky sexual behaviors [38].

Organizational facilitators reported involved those associated with intervention acceptability among youth, and this included accessibility and friendliness of intervention venue [33].

\section{Characteristics of the strategy of facilitating implementation}

Facilitators within the characteristics of the strategy of facilitating implementation domain were mentioned by six studies [32, 35-37, 40, 44]. These included implementation of intervention with fidelity [40, 44], dissemination of intervention information to community members [32, 36, 37], use of participatory facilitating methods, decreased corporal punishment [44] and collaboration among different stakeholders in delivering the intervention [32]. Another category of facilitators identified consisted of those correlated with young people's involvement in the intervention. Such facilitators included provision of incentives [32,37], building of a trusting relationship with young people, mobilization of community members to influence youth to attend the intervention, integration of intervention with other services and use of same age or peer implementers [32]. Further facilitators reported involved those linked to intervention acceptability among youth, such as use of same sex youth group [35,36] and use of different or mixed facilitating methods [35].

\section{Characteristics of the implementation object}

Facilitators within the characteristics of the implementation object domain were identified by four studies [32, 35-37]. Two groups of facilitators emerged: those associated with intervention acceptability among youth and those associated with intervention acceptability among implementers. Identified facilitators to intervention acceptability among youth included compatibility of intervention content with the needs of youth [35-37], same sex youth group [36,37] and detailed or comprehensive intervention content [37]. Compatibility of intervention content with the needs of youth and relative advantage of the intervention [32] were reported as facilitators to intervention acceptability among implementers.

\section{Characteristics of the users}

Four studies [32, 33, 37, 44] reported facilitators at the characteristics of the users level. Identified facilitators included training of implementers [32] and knowledge of implementers [44]. Additional facilitators reported involved those linked to intervention acceptability among youth, such as approachability or friendliness of implementers [33,37] and experience of implementers [37].

\section{Discussion}

This review identified and synthesized barriers and facilitators to HIV prevention interventions for reducing risky sexual behavior among youth (1524 years) worldwide based on quantitative, qualitative and mixed methods studies published in the last decade. The review found several multi-level barriers and facilitators to the success of HIV prevention interventions for reducing risky sexual behavior among youth. These multi-level barriers and facilitators included factors associated with the intervention, implementers of the intervention, recipients of the intervention, context of the intervention and strategy of implementing the intervention. Additionally, the review findings show that major barriers and facilitators to interventions targeting young people involved factors associated with context of the intervention and intervention recipients. Other important facilitators consisted of factors linked to strategy of implementing the intervention.

Similarities exist between this review's findings when comparing with existing literature. For example, Michielsen, 2010 [22] also reported barriers associated with the intervention (e.g., limited intervention content). Barriers linked to implementers of the intervention (e.g., adult implementers) were also identified in other reviews [21, 25]. Additionally, barriers related to context of the intervention (e.g., limited resources and social norms encouraging risky sexual behavior) were also found in previous reviews [19, 22, 45]. Findings of this review concur with other reviews [22, 23] that identified barriers related to strategy of delivering the intervention (e.g., failure to implement the intervention with fidelity). Furthermore, this review's findings are consistent with other reviews $[14,16]$ that found facilitators associated with implementers of the intervention (e.g., knowledge and 
experience of implementers). Other reviews [20,23,24] also identified facilitators correlated with strategy of implementing intervention (e.g., implementation of intervention with fidelity, use of a mixed delivery approach and integration of intervention with other services). Another review [45] also mentioned attributes of intervention recipients as factors determining the success of interventions targeting young people. Moreover, the findings of the current review are consistent with those of Ibrahim, 2014 [20] that reported facilitators linked to the intervention (e.g., comprehensive intervention content and duration of the intervention).

This review's findings, however, differ from previous reviews in that the present review found numerous barriers linked to intervention recipients (e.g., fear of relationship breakdown, lack of self-confidence, poor decision-making skills) that were not found in previous reviews [16, 19-25].

Furthermore, whilst other reviews [16] identified few facilitators associated with intervention recipients (e.g., gender, age and race), the current review found additional facilitators associated with intervention recipients (e.g., fear of pregnancy and sexually transmitted diseases, having high selfconfidence and having good problem skills). Moreover, previous reviews [16] identified few facilitators related to the context of the intervention, mainly organizational factors (e.g., supportive implementation climate), the present review identified additional facilitators associated with context of the intervention, mainly interpersonal factors (e.g., positive peer influence, parental advice, financial support from family), community factors (e.g., norms encouraging healthy sexual behaviors, norms encouraging discussion of sexual issues and religious beliefs discouraging risky sexual behaviors) and organizational factors (e.g., accessibility and friendliness of intervention venue). Additionally, the current review reported additional barriers associated with strategy of implementing the intervention (e.g., use of non-participatory facilitating methods, use of corporal punishment and sexual abuse) and additional facilitators associated with strategy of implementing the intervention (e.g., use of participatory facilitating methods, decreased corporal punishment, use of same age implementers and provision of incentives) not reported in previous reviews [16, 19-25]. The discordance in findings with other reviews may be due to the inclusion of qualitative data in the current review which may have helped to generate a more holistic evidence. Additionally, the discordance in findings may stem from the use of a theoretical framework to synthesize factors in this review which may have helped to identify additional barriers and facilitators.

Several limitations should be considered when interpreting the findings of this review. Few included studies [ $n=13]$ in this review is one of the limitations that could affect the generalizability of the findings. Another limitation is that majority of the included studies ( $\mathrm{n}=12$ ) were from in lowincome countries, and therefore not representative of all international contexts. Due to the lack of studies from high-income countries, it was impossible to determine whether or not the barriers and facilitators found in this review differed by geographical location (e.g., between low-income and high-income countries). Additionally, this review was limited to only original peer-reviewed studies; conducted in educational, healthcare and community settings; written in English language; and published between January 2010 and May 2020, which may result in potential publication bias. Furthermore, majority of the studies included in this review collected data through self-reports which may have compromised the quality of the evidence as self-reports are prone to both over- and under-reporting [46]. Whitehead, 2016 [47] argue that the approach to data collection is highly likely to influence the nature and quality of data collected. Another reason for concern is that determinant frameworks such as the one used to synthesize the factors in this review do not examine causal relationships between the barriers or facilitators and outcomes [17], it is therefore difficult to determine with greater certainty whether or not the identified factors influence intervention success.

The review on the other hand, had its strengths. To the authors' knowledge, this is the first systematic review incorporating different types of studies to synthesize existing global evidence on barriers and facilitators to HIV prevention interventions for reducing risky sexual behavior among youth. The use of a mixed methods approach most likely result in a more comprehensive understanding of the topic under study [28]. Moreover, the review provides a recent summary of literature from 2010-2020. Another strength of this review is the use of a theoretical implementation-framework to synthesize the factors. This may have helped to highlight key barriers and facilitators, identify gaps in literature and formulate theory-driven strategies to facilitate improvements. To the authors' knowledge, this is the first review to synthesize barriers and facilitators to HIV prevention interventions for reducing risky sexual behavior in youth using a theory. Using theory to examine barriers and facilitators adds to the growing body of evidence for the utility of theory to synthesize the factors. Additional strength is that other important population groups in HIV prevention interventions for young people such as implementers, community and family members were represented in this review which may have helped to provide more evidence. Futhermore, most of the included studies $(n=9)$ were of good quality, and four studies were of fair quality. Therefore, the review findings can reliably inform policies and programmatic strategies to promote the success of HIV prevention interventions for youth.

This systematic review has important implications for practice, policy and research. Considering that the review findings suggest that several multilevel barriers and facilitators influence interventions targeting youth, there is need for multi-level approaches to address these factors and enhance intervention success. Multi-level interventions consider barriers and facilitators at multiple levels, evaluate the inter-relationships between these factors, and formulate strategies to enhance intervention success [48]. Evidence suggests that multi-level approaches contribute to the success of an intervention [49]. Furthermore, to promote intervention success, the findings of this review imply the need for combination approaches. Research has established that interventions incorporating different prevention strategies are associated with positive outcomes [45, 50, 51].

Furthermore, the current review's findings suggest that major barriers to interventions targeting youth included factors associated with the context of the intervention and intervention recipients. To enhance intervention success, there is need for more intervention efforts to be directed towards removing barriers associated with intervention recipients and context of the intervention. Approaches that have been found successful to address barriers linked to context of the intervention include peer education interventions [52], family-based interventions [53], school-based interventions, community-based interventions, health facility-based interventions [54] and structural interventions [55]. Behavioral or individual risk reduction

Page $7 / 18$ 
interventions that use behavior change techniques (e.g., condom-use, communication and motivation enhancement, psycho-education and assertiveness skills training) have been found effective to remove barriers associated with intervention recipients [16, 56].

In this review, factors associated with the strategy of implementing the intervention were identified as barriers and facilitators to the success of HIV prevention interventions targeting youth. These findings imply the need for intervention implementers to be sensitive of the delivery strategies they use as some implementation methods are counterproductive. Also, there is need for intervention implementers to ensure that interventions are implemented with fidelity or as intended in order to enhance intervention success. Evidence suggests that implementation of intervention with fidelity promotes intervention success $[23,24]$.

Other barriers and facilitators to interventions targeting youth found in the present review included factors associated with the intervention. As guided by Sekhon, 2017's [57] theoretical framework of acceptability, these findings highlight the importance for intervention designers to develop interventions that are compatible with the needs and values of the target population in order to enhance program success. To identify the needs of the target population and incorporate them into the intervention, it is recommended that preliminary formative research be conducted as it is linked to intervention success [16].

Factors associated with implementers of the intervention were some of the barriers and facilitators to interventions for young people reported in this review. These results suggest the need to recruit implementers with desirable characteristics, train them, and provide monitoring, support and supervision in order to promote intervention success. Research has demonstrated that use of implementers with attractive attributes (e.g., same age or peer implementers) promotes intervention success $[16,21]$.

Given the small number of studies identified in the current review, further studies of this nature are recommended. Moreover, high-income countries may have additional barriers and facilitators specific to their context. Further research is needed to identify barriers and facilitators to HIV prevention interventions targeting youth in high-income countries. As determinant frameworks do not examine causal relationships between barriers or facilitators and outcomes [17], it is recommended that further experimental studies be conducted to identify and determine the most effective, feasible and acceptable strategies to enhance intervention efficacy. Also, it is recommended that future studies utilize theoretical frameworks to highlight the most important factors that influence interventions targeting youth and formulate theory-driven strategies to promote intervention success.

\section{Conclusion}

This systematic review synthesized current global evidence on barriers and facilitators to HIV prevention interventions for reducing risky sexual behavior among youth. The findings suggest that numerous multi-level barriers and facilitators affect HIV prevention interventions for reducing risky sexual behavior among youth. The multi-level barriers and facilitators identified included factors associated with the intervention, implementers of the intervention, recipients of the intervention, context of the intervention, and strategy of implementing the intervention. Furthermore, the review findings suggest that major barriers and facilitators to interventions targeting young people comprised of factors associated with the context of the intervention and intervention recipients. Other important facilitators involved factors linked to the strategy of implementing the intervention. The findings of the present review highlight the need for multi-level and combination approaches to remove barriers and facilitate intervention success. Furthermore, this review's findings suggest the need for further research on barriers and facilitators to HIV prevention interventions targeting young people.

\section{Abbreviations}

HIV: Human Immunodeficiency Virus; JBI: Joanna Briggs Institute; PRISMA: Preferred Reporting Items for Systematic Reviews and Meta-Analysis; UNAIDS: Joint United Nations Programme on HIV/AIDS; WHO: World Health Organization

\section{Declarations}

\section{Ethical approval and consent to participate}

Not Applicable.

\section{Consent for publication}

Not applicable.

\section{Availability of data and materials}

Data that support the findings of this study are available from the corresponding author on reasonable request.

\section{Competing interests}


The authors declare that they have no competing interests.

\section{Funding}

This research was funded by the Edith Cowan University under a Higher Degree by Research Scholarship awarded to FM. Beyond funding support, the funder had no direct role in the study design, collection, analysis and interpretation of data, or writing the manuscript.

\section{Authors' contributions}

FM, EA and ATB conceptualized and designed the study, screened and critically appraised the studies. Literature search, data extraction and analysis and writing of the first manuscript draft were done by FM. EA, ATB and AB critically reviewed the work and provided feedback on the manuscript. All authors have read and approved the final manuscript.

\section{Acknowledgements}

The authors wish to thank librarian, Lisa Webb for her support with developing the review protocol, and Maggie Zgambo (PhD) for her useful comments and discussions that helped to improve the manuscript.

\section{Authors' information}

${ }^{1}$ School of Nursing \& Midwifery, Edith Cowan University, 270 Joondalup Dr, Joondalup WA 6027, Australia. ${ }^{2}$ Centre for Rural Health, School of Nursing and Public Health, University of KwaZulu-Natal, Howard College Campus, Durban, South Africa, and Health Systems Research Unit, SAMRC, South Africa.

\section{References}

1. World Health Organization. Why the HIV epidemic is not over. Available at: https://www.who.int/news-room/spotlight/why-the-hiv-epidemic-isnot-over. (2020). Accessed October 9, 2020.

2. Joint United Nations Programme on HIV/AIDS. AIDSinfo: Global data on HIV epidemiology and response. Available at: http://aidsinfo.unaids.org/. (2021). Accessed September 21, 2021.

3. United Nations Children's Fund. Children and AIDS: Statistical Update. (2017).

4. Centers for Disease Control and Prevention. The Social Ecological Model: A Framework for Prevention.Available at: http://www.cdc.gov/violenceprevention/overview/social-ecologicalmodel.html. (2014). Accessed May 15, 2020.

5. Kaufman MR, Cornish F, Zimmerman RS, Johnson BT. Health behavior change models for HIV prevention and AIDS care: practical recommendations for a multi-level approach. Journal of acquired immune deficiency syndromes (1999). 2014;66(Suppl 3):S250.

6. DiClemente RJ, Crittenden CP, Rose E, et al. Psychosocial predictors of HIV-associated sexual behaviors and the efficacy of prevention interventions in adolescents at-risk for HIV infection: what works and what doesn't work?. Psychosomatic Medicine. 2008;70(5):598-605.

7. Eaton L, Flisher AJ, Aarø LE. Unsafe sexual behaviour in South African youth. Social science \& medicine. 2003;56(1):149-65.

8. Govender K, Cowden RG, Asante KO, George G, Reardon C. Sexual risk behavior: A multi-system model of risk and protective factors in South African adolescents. Prevention Science. 2019;20(7):1054-65.

9. Harper GW, Riplinger AJ, Neubauer LC, Murphy AG, Velcoff J, Bangi AK. Ecological factors influencing HIV sexual risk and resilience among young people in rural Kenya: Implications for prevention. Health education research. 2014;29(1):131-46.

10. Dancy BL, Jere DL, Kachingwe SI, Kaponda CP, Norr JL, Norr KF. HIV risk reduction intervention for rural adolescents in Malawi. Journal of HIV/AIDS \& social services. 2014;13(3):271-91.

11. Van Staden A, Badenhorst G. Reviewing gender and cultural factors associated with HIV/AIDS among university students in the South African context. Curationis. 2009;32(4):19-28.

12. Hosek S, Pettifor A. HIV Prevention Interventions for Adolescents. Current HIV/AIDS Reports. 2019;16(1):120-8.

13. Muthoni CN, Kneipp SM, Gichane MW, Caiola CE, Pettifor AE, Williams JR. A systematic review of HIV interventions for young women in subSaharan Africa. AIDS and Behavior. 2020;24:3395-413.

14. Johnson BT, Scott-Sheldon LJ, Huedo-Medina TB, Carey MP. Interventions to reduce sexual risk for human immunodeficiency virus in adolescents: a meta-analysis of trials, 1985-2008. Arch Pediatr Adolesc Med. 2011;165(1):77-84.

15. Picot J, Shepherd J, Kavanagh J, et al. Behavioural interventions for the prevention of sexually transmitted infections in young people aged 1319 years: a systematic review. Health Educ Res. 2012;27(3):495-512.

16. Protogerou C, Johnson BT. Factors Underlying the success of Behavioral HIV-Prevention Interventions for Adolescents: A Meta-Review. AIDS and Behavior. 2014;18:1847-1863.

17. Nilsen P. Making sense of implementation theories, models and frameworks. Implementation Science. 2015;10:53. 
18. Weatherson KA, Gainforth HL, Jung ME. A theoretical analysis of the barriers and facilitators to the implementation of school-based physical activity policies in Canada: a mixed methods scoping review. Implementation Science. 2017;12:41.

19. Harrison A, Newell ML, Imrie J, Hoddinott G. HIV prevention for South African youth: which interventions work? A systematic review of current evidence. BMC public health. 2010;10(1):1-2.

20. Ibrahim S, Sidani S. Community based HIV prevention intervention in developing countries: a systematic review. Advances in Nursing. 2014;2014.

21. Lazarus JV, Sihvonen-Riemenschneider H, Laukamm-Josten U, Wong F, Liljestrand J. Systematic review of interventions to prevent the spread of sexually transmitted infections, including HIV, among young people in Europe. Croatian medical journal. 2010;51(1):74-84.

22. Michielsen K, Chersich MF, Luchters S, De Koker P, Van Rossem R, Temmerman M. Effectiveness of HIV prevention for youth in sub-Saharan Africa: systematic review and meta-analysis of randomized and nonrandomized trials. Aids. 2010;24(8):1193-202.

23. Mwale M, Muula AS. Systematic review: a review of adolescent behavior change interventions [BCI] and their effectiveness in HIV and AIDS prevention in sub-Saharan Africa. BMC public health. 2017;17(1):1-9.

24. Sani AS, Abraham C, Denford S, et al. School-based sexual health education interventions to prevent STI/HIV in sub-Saharan Africa: a systematic review and meta-analysis. BMC public health. 2016;16(1):1-26.

25. Scott-Sheldon AJL, Walstrom P, Harrison AC, Kalichman SP, Carey M. Sexual risk reduction interventions for HIV prevention among South African Youth: a meta-analytic review. Current HIV research. 2013;11(7):549-58.

26. Aromataris E, Munn Z, eds. Joanna Briggs Institute Reviewer's Manual [Internet]. Adelaide: Joanna Briggs Institute, 2017. Available at: https://reviewersmanual.joannabriggs.org/. Accessed April 26, 2020.

27. Moher D, Liberati A, Tetzlaff J, Altman DG. Preferred reporting items for systematic reviews and meta-analyses: the PRISMA statement. Int J Surg. 2010;8(5):336-41.

28. Teddlie C, Tashakkori A. Foundations of mixed methods research: Integrating quantitative and qualitative approaches in the social and behavioral sciences. Sage; 2009.

29. Mbengo F, Adama E, Towell-Barnard A, Bhana A. Barriers and facilitators to effectiveness of Human Immunodeficiency Virus (HIV) prevention interventions for reducing risky sexual behaviour in youth (15-24 years): A mixed methods systematic review protocol. PROSPERO 2020 CRD42020187272. Available at: https://www.crd.york.ac.uk/prospero/display_record.php?ID=CRD42020187272. Accessed October 10, 2020.

30. Hong QN, Pluye P, Bujold M, Wassef M. Convergent and sequential synthesis designs: implications for conducting and reporting systematic reviews of qualitative and quantitative evidence. Systematic Reviews. 2017;6(1):61.

31. Thomas J, Harden A. Methods for the thematic synthesis of qualitative research in systematic reviews. BMC Medical Research Methodology. 2008;8:45.

32. Al-Iryani B, Al-Sakkaf K, Basaleem H, Kok G, van den Borne B. Process evaluation of a three-year community-based peer education intervention for HIV prevention among Yemeni young people. International quarterly of community health education. 2011;31(2):133-154.

33. Aung PP, Ryan C, Bajracharya A, et al. Effectiveness of an integrated community-and clinic-based intervention on HIV testing, HIV knowledge, and sexual risk behavior of young men who have sex with men in Myanmar. Journal of Adolescent Health. 2017;60(2):S45-S53.

34. Garofalo R, Johnson AK, Kuhns LM, Cotton C, Joseph H \& Margolis A. Life skills: evaluation of a theory-driven behavioral HIV prevention intervention for young transgender women. Journal of Urban Health. 2012;89(3):419-431.

35. Greene GJ, Madkins K, Andrews K, Dispenza J, Mustanski B. Implementation and evaluation of the Keep It Up! online HIV prevention intervention in a community-based setting. AIDS Education and Prevention. 2016;28(3):231-245.

36. Jewkes R, Wood K, Duvvury N. 'I woke up after I joined Stepping Stones': meanings of an HIV behavioural intervention in rural South African young people's lives. Health education research. 2010;25(6):1074-1084.

37. Morrison-Beedy D, Passmore D, Carey MP. Exit interviews from adolescent girls who participated in a sexual risk-reduction intervention: implications for community-based health education promotion for adolescents. Journal of midwifery \& women's health. 2013;58(3):313-320.

38. Musiimenta A. Contextual mediators influencing the effectiveness of behavioural change interventions: A case of HIV/AIDS prevention behaviours. Online journal of public health informatics. 2012;4(2).

39. Ridgeway K, Lenzi R, Packer C, et al. 'I married when I was 16 ... due to poverty, I had no other way': multi-level factors influencing HIV-related sexual risk behaviours among adolescent girls in Zambézia, Mozambique. Culture, Health \& Sexuality. 2020,1-17.

40. Rohrbach LA, Donatello RA, Moulton BD, Afifi AA, Meyer KI, De Rosa CJ. Effectiveness Evaluation of It's Your Game: Keep It Real, a Middle School HIV/Sexually Transmitted Infection/Pregnancy Prevention Program. Journal of Adolescent Health. 2019;64(3):382-389.

41. Sales JM, Brown JL, DiClemente RJ, Rose E. Exploring factors associated with nonchange in condom use behavior following participation in an STI/HIV prevention intervention for African-American adolescent females. AIDS research and treatment. $2012 ; 2012$.

42. Sales JM, DiClemente RJ, Davis TP, Sullivan S. Exploring why young African American women do not change condom-use behavior following participation in an STI/HIV prevention intervention. Health Education Research. 2012a;27(6):1091-1101. 
43. Wamoyi J, Mshana G, Doyle AM, Ross DA. Recall, relevance and application of an in-school sexual and reproductive health intervention 7-9 years later: perspectives of rural Tanzanian young people. Health promotion international. 2012;28(3):311-321.

44. Wight D, Plummer M, Ross D. The need to promote behaviour change at the cultural level: one factor explaining the limited impact of the MEMA kwaVijana adolescent sexual health intervention in rural Tanzania. A process evaluation. BMC Public Health. 2012;12(1):788.

45. Ahankari AS, Wray J, Jomeen J, Hayter M. The effectiveness of combined alcohol and sexual risk taking reduction interventions on the sexual behaviour of teenagers and young adults: a systematic review. Public health. 2019;173:83-96.

46. Demetriou C, Ozer BU, Essau CA. Self-Report Questionnaires. In: Cautin RL, Lilienfield, SO. (eds). The Encyclopedia of Clinical Psychology, First Edition; 2015.

47. Whitehead D, Whitehead L. Sampling data and data collection in qualitative research. In: Schneider Z, Whitehead D. (eds). Nursing and midwifery research: Methods and appraisal for evidence based practice. 5th ed. Chapter 7, pp. 111-123. Australia: Elsevier; 2016.

48. Lewis CF, Crawford ND. Multi-level interventions/Structural Approaches to HIV Prevention. In: Hope TJ, Richman DD, Stevensen M. (eds). Encyclopedia of AIDS. Springer, New York, NY; 2018.

49. DiClemente RJ, Patel N. HIV Prevention Among Youth: Designing Effective Evidence-Based HIV Risk-Reduction Programs for Adolescents. In: Chenneville T. (eds). A Clinical Guide to Pediatric HIV. Springer, Cham; 2016.

50. Thurman TR, Kidman R, Carton TW, Chiroro P. Psychological and behavioral interventions to reduce HIV risk: evidence from a randomized control trial among orphaned and vulnerable adolescents in South Africa. AIDS care. 2016;28(sup1):8-15.

51. Firestone R, Rivas J, Lungo S, et al. Effectiveness of a combination prevention strategy for HIV risk reduction with men who have sex with men in Central America: a mid-term evaluation. BMC Public Health. 2014;14(1):1-5.

52. Mahat G, Scoloveno MA. Effectiveness of adolescent peer education programs on reducing HIV/STI risk: an integrated review. Research and Theory for Nursing Practice. 2018;32(2):168-98.

53. Ocasio MA, Lozano A, Lee TK, Feaster DJ, Carrico A, Prado G. Efficacy of a Family-Based Intervention for HIV Prevention with Hispanic Adolescents with Same Gender Sexual Behaviors. Prevention Science. 2021;25:1-1.

54. Mavedzenge SM, Doyle AM, Ross DA. HIV prevention in young people in sub-Saharan Africa: a systematic review. Journal of Adolescent Health. 2011;49(6):568-86.

55. Baird SJ, Garfein RS, Mclntosh CT, Özler B. Effect of a cash transfer programme for schooling on prevalence of HIV and herpes simplex type 2 in Malawi: a cluster randomised trial. The Lancet. 2012;379(9823):1320-9.

56. Adejumo AO. Influence of psycho-demographic factors and effectiveness of psycho-behavioural interventions on sexual risk behaviour of inschool adolescents in Ibadan City. IFE PsychologIA: An International Journal. 2012;20(1):1-8.

57. Sekhon M, Cartwright M, Francis JJ. Acceptability of healthcare interventions: an overview of reviews and development of a theoretical framework. BMC health services research. 2017;17(1):1-3.

\section{Tables}

Table 1

Characteristics of included studies 


\begin{tabular}{|c|c|c|c|c|c|c|c|}
\hline Author, year \& title & $\begin{array}{l}\text { Phenomena of } \\
\text { interest }\end{array}$ & $\begin{array}{l}\text { Study } \\
\text { location }\end{array}$ & Setting & Study design & $\begin{array}{l}\text { Population/sample } \\
\text { size }\end{array}$ & Methods & Data analysis \\
\hline $\begin{array}{l}\text { Al-iryani, } 2011 \\
{[32] \text {. Process }} \\
\text { evaluation of a three- } \\
\text { year community- } \\
\text { based peer } \\
\text { education } \\
\text { intervention for HIV } \\
\text { prevention among } \\
\text { Yemeni young } \\
\text { people }\end{array}$ & $\begin{array}{l}\text { To highlight the } \\
\text { factors } \\
\text { facilitated or } \\
\text { inhibited } \\
\text { community based } \\
\text { peer education }\end{array}$ & Aden, Yemen & $\begin{array}{l}\text { Community } \\
\text { setting } \\
\text { (Four poor and } \\
\text { vulnerable } \\
\text { areas) }\end{array}$ & $\begin{array}{l}\text { Qualitative } \\
\text { study, design not } \\
\text { specified }\end{array}$ & $\begin{array}{l}\text { (16 community } \\
\text { focal points, } 21 \\
\text { peer educators, } \\
10 \text { targeted } \\
\text { young people in } \\
\text { communities, } 3 \\
\text { young female sex } \\
\text { workers, } 2 \text { local } \\
\text { council members) } \\
\text { - age not } \\
\text { specified }\end{array}$ & $\begin{array}{l}\text { Focus group } \\
\text { discussions, in- } \\
\text { depth } \\
\text { interviews }\end{array}$ & Thematic analysis \\
\hline $\begin{array}{l}\text { Aung, } 2017 \\
\text { [33]. Effectiveness of } \\
\text { an integrated } \\
\text { community-and } \\
\text { clinic-based } \\
\text { intervention on HIV } \\
\text { testing, HIV }\end{array}$ & $\begin{array}{l}\text { To evaluate the } \\
\text { effectiveness and } \\
\text { acceptability } \\
\text { of integrated, } \\
\text { community-based, } \\
\text { and clinic-based } \\
\text { intervention }\end{array}$ & $\begin{array}{l}\text { Pathein, } \\
\text { Mawlamyine, } \\
\text { Bago, Kalay, } \\
\text { Magwe and } \\
\text { Thlyin } \\
\text { Myanmar }\end{array}$ & $\begin{array}{l}\text { Community } \\
\text { and healthcare } \\
\text { setting } \\
\text { (Six townships } \\
\text { Community } \\
\text { and clinic) }\end{array}$ & $\begin{array}{l}\text { Mixed methods study } \\
\text { design - qualitative } \\
\text { component to } \\
\text { examine } \\
\text { acceptability } \\
\text { (barriers and } \\
\text { facilitators) }\end{array}$ & $\begin{array}{l}54 \text { young men } \\
\text { who have sex with } \\
\text { men aged } 15-24 \\
\text { years, } 18 \text { peer } \\
\text { educators - age } \\
\text { not specified }\end{array}$ & $\begin{array}{l}\text { Focus group } \\
\text { discussions }\end{array}$ & $\begin{array}{l}\text { Thematic analysis, } \\
\text { Atlas.ti version } 6.1\end{array}$ \\
\hline
\end{tabular}

sexual risk behavior

of young men who

have sex with men in

Myanmar

Garofalo, 2012

evaluation of a

theory-driven

behavioral HIV

prevention

intervention for

young transgender

women
[34]. Life skills:

$\begin{array}{lll}\begin{array}{l}\text { To assess the } \\ \text { efficacy, feasibility } \\ \text { and acceptability } \\ \text { of Life Skills } \\ \text { intervention }\end{array} & \begin{array}{l}\text { Chicago } \\ \text { United }\end{array} & \begin{array}{l}\text { Community } \\ \text { setting }\end{array} \\ & \text { America } & \begin{array}{l}\text { (1 urban } \\ \text { geographical } \\ \text { area }\end{array} \\ & \text { night clubs, } \\ & \text { pageants/balls, } \\ & \text { local parks, } \\ & \text { youth centre, } \\ & \text { community } \\ & \text { organizations) }\end{array}$

\section{Greene, 2016}

To assess the

United

Community

[35]. Implementation and evaluation of the Keep It Up! online HIV prevention intervention in a community-based setting

$\begin{array}{ll}\text { effectiveness and } & \text { States of } \\ \text { acceptability } & \text { America }\end{array}$

of online HIV

prevention

intervention setting

(Local non-

profit

community-

based

organization)
Quasi-experimental 51 Transgender Audioone group, beforeafter design women aged 16 24 years

\section{computer- assisted self- interviewing technology}

\section{Descriptive analyses}

chi-square tests, nonparametric tests (Wilcoxon signed ranks tests), primary analyses, sensitivity analyses, intention-to-treat approach, correlations

\begin{tabular}{|c|c|c|c|c|c|c|c|}
\hline $\begin{array}{l}\text { Jewkes, } 2010 \text { [36]. 'I } \\
\text { woke up after I } \\
\text { joined Stepping } \\
\text { Stones': meanings of } \\
\text { an HIV behavioural } \\
\text { intervention in rural } \\
\text { South African young } \\
\text { people's lives }\end{array}$ & $\begin{array}{l}\text { To explore how } \\
\text { participants made } \\
\text { meaning from the } \\
\text { Stepping Stones } \\
\text { intervention and } \\
\text { how it influenced } \\
\text { their lives }\end{array}$ & $\begin{array}{l}\text { Eastern } \\
\text { Cape } \\
\text { Province } \\
\text { South Africa }\end{array}$ & $\begin{array}{l}\text { Community } \\
\text { setting } \\
\text { (Poor, rural } \\
\text { formerly } \\
\text { subsistence } \\
\text { farming area) }\end{array}$ & $\begin{array}{l}\text { Qualitative study, } \\
\text { design not specified }\end{array}$ & $\begin{array}{l}\text { (11 women, } 10 \\
\text { men) - majority } \\
\text { aged } 17-21 \text { years, } \\
4 \text { focus groups }\end{array}$ & $\begin{array}{l}\text { In-depth } \\
\text { interviews, } \\
\text { focus groups }\end{array}$ & $\begin{array}{l}\text { Content analysis, } \\
\text { analytic induction }\end{array}$ \\
\hline $\begin{array}{l}\text { Morrison-Beedy, } \\
2013 \text { [37]. Exit } \\
\text { interviews from } \\
\text { adolescent girls who } \\
\text { participated in a } \\
\text { sexual risk-reduction } \\
\text { intervention: } \\
\text { implications for } \\
\text { community-based }\end{array}$ & $\begin{array}{l}\text { To describe the } \\
\text { experiences of } \\
\text { adolescent girls } \\
\text { who participated in } \\
\text { a sexual risk- } \\
\text { reduction } \\
\text { intervention }\end{array}$ & $\begin{array}{l}\text { United } \\
\text { States of } \\
\text { America }\end{array}$ & $\begin{array}{l}\text { Community } \\
\text { setting } \\
\text { (Poor urban } \\
\text { area, } \\
\text { community- } \\
\text { based } \\
\text { organization) }\end{array}$ & $\begin{array}{l}\text { Qualitative } \\
\text { descriptive study } \\
\text { design }\end{array}$ & $\begin{array}{l}26 \text { African } \\
\text { American urban, } \\
\text { low income girls } \\
\text { aged 15-19 years }\end{array}$ & $\begin{array}{l}\text { Semi- } \\
\text { structured } \\
\text { interviews }\end{array}$ & $\begin{array}{l}\text { Thematic analysis, } \\
\text { Atlas.ti }\end{array}$ \\
\hline
\end{tabular}

community-based

health education

promotion for

adolescents

\begin{tabular}{|c|c|c|c|c|c|c|c|}
\hline $\begin{array}{l}\text { Musiimenta, } 2012 \\
\text { [38]. Contextual } \\
\text { mediators } \\
\text { influencing the } \\
\text { effectiveness of } \\
\text { behavioural change } \\
\text { interventions: A case } \\
\text { of HIV/AIDS }\end{array}$ & $\begin{array}{l}\text { To identify } \\
\text { contextual } \\
\text { mediators } \\
\text { that influence the } \\
\text { youth's decision to } \\
\text { adopt and maintain } \\
\text { the HIV/AIDS } \\
\text { preventive }\end{array}$ & Uganda & $\begin{array}{l}\text { Education } \\
\text { setting } \\
\text { (Secondary } \\
\text { schools) }\end{array}$ & $\begin{array}{l}\text { Qualitative study, } \\
\text { design not specified }\end{array}$ & $\begin{array}{l}20 \text { youth - age } \\
\text { not specified }\end{array}$ & $\begin{array}{l}\text { Individual } \\
\text { telephone } \\
\text { interviews }\end{array}$ & $\begin{array}{l}\text { Grounded theory's } \\
\text { three-stage coding } \\
\text { process analysis(open, } \\
\text { axial and selective } \\
\text { coding) }\end{array}$ \\
\hline
\end{tabular}




\begin{tabular}{|c|c|c|c|c|c|c|c|}
\hline $\begin{array}{l}\text { Ridgeway, } 2020 \\
\text { [39] 'I married when } \\
\text { I was } 16 \ldots \text { due to } \\
\text { poverty, I had no } \\
\text { other way': multi- } \\
\text { level factors } \\
\text { influencing HIV- } \\
\text { related sexual risk } \\
\text { behaviours among } \\
\text { adolescent girls in } \\
\text { Zambézia, } \\
\text { Mozambique }\end{array}$ & $\begin{array}{l}\text { To } \\
\text { explore individual, } \\
\text { interpersonal- and } \\
\text { household-level } \\
\text { factors } \\
\text { influencing HIV- } \\
\text { related sexual risk } \\
\text { behavior among } \\
\text { adolescent girls } \\
\text { who participated in } \\
\text { the Women First } \\
\text { intervention }\end{array}$ & $\begin{array}{l}\text { Zambézia } \\
\text { Mozambique }\end{array}$ & $\begin{array}{l}\text { Community } \\
\text { setting } \\
\text { (Poor rural } \\
\text { area) }\end{array}$ & $\begin{array}{l}\text { Qualitative study, } \\
\text { design not specified }\end{array}$ & $\begin{array}{l}28 \text { adolescent } \\
\text { girls aged } 13-19 \\
\text { years and mean } \\
\text { age } 16 \text { years, ( } 30 \\
\text { household heads, } \\
53 \text { influential } \\
\text { men) - age not } \\
\text { specified }\end{array}$ & $\begin{array}{l}\text { In-depth } \\
\text { interviews }\end{array}$ & $\begin{array}{l}\text { Primary analysis, } \\
\text { inductive approach, } \\
\text { within- case and cross- } \\
\text { case comparative } \\
\text { analysis }\end{array}$ \\
\hline $\begin{array}{l}\text { Rohrbach, } 2019 \\
\text { [40]. Effectiveness } \\
\text { Evaluation of It's } \\
\text { Your Game: Keep It } \\
\text { Real, a Middle } \\
\text { School HIV/Sexually } \\
\text { Transmitted } \\
\text { Infection/Pregnancy } \\
\text { Prevention Program }\end{array}$ & $\begin{array}{l}\text { To assess } \\
\text { effectiveness and } \\
\text { implementation of } \\
\text { the } \\
\text { HIV/STI/Pregnancy } \\
\text { prevention } \\
\text { program }\end{array}$ & $\begin{array}{l}\text { Los Angeles } \\
\text { County } \\
\text { United } \\
\text { States of } \\
\text { America }\end{array}$ & $\begin{array}{l}\text { Education } \\
\text { setting } \\
\text { (24 urban } \\
\text { public middle } \\
\text { schools) }\end{array}$ & $\begin{array}{l}\text { Quasi-experimental } \\
\text { non-equivalent two- } \\
\text { group, before-after } \\
\text { study design }\end{array}$ & $\begin{array}{l}44 \text { teachers - age } \\
\text { not specified, } \\
\text { trained program } \\
\text { staff - sample size } \\
\text { and age not } \\
\text { specified }\end{array}$ & $\begin{array}{l}\text { Implementation } \\
\text { logs, } \\
\text { observations - } \\
\text { to examine } \\
\text { implementation } \\
\text { (barriers and } \\
\text { facilitators) }\end{array}$ & $\begin{array}{l}\text { Not specified -to } \\
\text { examine } \\
\text { implementation(barriers } \\
\text { and facilitators) }\end{array}$ \\
\hline $\begin{array}{l}\text { Sales, } 2012 \\
\text { [41]. Exploring } \\
\text { factors associated } \\
\text { with nonchange in } \\
\text { condom use behavior } \\
\text { following } \\
\text { participation in an } \\
\text { STI/HIV prevention } \\
\text { intervention for } \\
\text { African-American } \\
\text { adolescent females }\end{array}$ & $\begin{array}{l}\text { To examine factors } \\
\text { associated with } \\
\text { adolescents' failure } \\
\text { to improve their } \\
\text { condom use } \\
\text { behaviors after } \\
\text { participating in an } \\
\text { STI/HIV prevention } \\
\text { intervention. }\end{array}$ & $\begin{array}{l}\text { Atlanta, } \\
\text { Georgia } \\
\text { United } \\
\text { States of } \\
\text { America }\end{array}$ & $\begin{array}{l}\text { Healthcare } \\
\text { setting } \\
\text { (3 downtown } \\
\text { clinics) }\end{array}$ & $\begin{array}{l}\text { Randomized } \\
\text { controlled trial } \\
\text { design }\end{array}$ & $\begin{array}{l}205 \text { African- } \\
\text { American } \\
\text { adolescent } \\
\text { females aged 15- } \\
21 \text { years and } \\
\text { mean age } 17.9 \\
\text { years }\end{array}$ & $\begin{array}{l}\text { Audio } \\
\text { computer } \\
\text { assisted self- } \\
\text { interview, self- } \\
\text { collected } \\
\text { vaginal } \\
\text { swab }\end{array}$ & $\begin{array}{l}\text { Descriptive statistics, } \\
\text { independent samples } t \text { - } \\
\text { tests, chi-square } \\
\text { analyses, multivariable } \\
\text { logistic regression, } \\
\text { repeated measure } \\
\text { MANOVA, univariate } \\
\text { repeated measures } \\
\text { ANOVAs }\end{array}$ \\
\hline $\begin{array}{l}\text { Sales, } 2012 \mathrm{a} \\
\text { [42]. Exploring why } \\
\text { young African } \\
\text { American women do } \\
\text { not change condom- } \\
\text { use behavior } \\
\text { following } \\
\text { participation in an } \\
\text { STI/HIV prevention } \\
\text { intervention }\end{array}$ & $\begin{array}{l}\text { To identify factors } \\
\text { associated } \\
\text { with young } \\
\text { African American } \\
\text { females' lack of } \\
\text { increase in condom } \\
\text { use post- } \\
\text { participation in an } \\
\text { HIV prevention } \\
\text { intervention }\end{array}$ & $\begin{array}{l}\text { Atlanta, } \\
\text { Georgia } \\
\text { United } \\
\text { States of } \\
\text { America }\end{array}$ & $\begin{array}{l}\text { Healthcare } \\
\text { setting } \\
(2 \text { downtown } \\
\text { sexual health } \\
\text { clinics) }\end{array}$ & $\begin{array}{l}\text { Qualitative grounded } \\
\text { theory study design }\end{array}$ & $\begin{array}{l}50 \text { young } \\
\text { African American } \\
\text { women aged 18- } \\
23 \text { years and } \\
\text { mean age } 20.5 \\
\text { years }\end{array}$ & $\begin{array}{l}\text { Semi- } \\
\text { structured } \\
\text { interviews }\end{array}$ & $\begin{array}{l}\text { Grounded theory's } \\
\text { three-stage coding } \\
\text { process analysis (open, } \\
\text { axial and selective } \\
\text { coding); } \\
\text { kappa coefficient } \\
\text {;independent coding; } \\
\text { Nvivo version } 9\end{array}$ \\
\hline $\begin{array}{l}\text { Wamoyi, } 2012 \\
\text { [43]. Recall, } \\
\text { relevance and } \\
\text { application of an in- } \\
\text { school sexual and } \\
\text { reproductive health } \\
\text { intervention 7-9 } \\
\text { years later: } \\
\text { perspectives of rural } \\
\text { Tanzanian young } \\
\text { people }\end{array}$ & $\begin{array}{l}\text { To explore young } \\
\text { people's } \\
\text { memories and } \\
\text { views of the } \\
\text { relevance of } \\
\text { the sexual and } \\
\text { reproductive } \\
\text { health intervention } \\
\text { and their ability to } \\
\text { apply what they } \\
\text { had learned 7-9 } \\
\text { years after } \\
\text { exposure to the } \\
\text { intervention }\end{array}$ & $\begin{array}{l}\text { Mwanza } \\
\text { Tanzania }\end{array}$ & $\begin{array}{l}\text { Community } \\
\text { setting } \\
\text { (Rural area) }\end{array}$ & $\begin{array}{l}\text { Qualitative study, } \\
\text { design not specified }\end{array}$ & $\begin{array}{l}23 \text { rural } \\
\text { Tanzanian young } \\
\text { people (males } \\
\text { aged } 24-29 \text { years } \\
\text { and females aged } \\
24-30 \text { years) }\end{array}$ & $\begin{array}{l}\text { In-depth } \\
\text { interviews }\end{array}$ & $\begin{array}{l}\text { Preliminary } \\
\text { analysis, grounded } \\
\text { theory's three-stage } \\
\text { coding process analysis } \\
\text { (open, axial and } \\
\text { selective coding), Nvivo } \\
\text { version } 7\end{array}$ \\
\hline $\begin{array}{l}\text { Wight, } 2012 \text { [44]. } \\
\text { The need to promote } \\
\text { behaviour change at } \\
\text { the cultural level: } \\
\text { one factor explaining } \\
\text { the limited impact of } \\
\text { the MEMA } \\
\text { kwaVijana } \\
\text { adolescent sexual } \\
\text { health intervention } \\
\text { in rural Tanzania }\end{array}$ & $\begin{array}{l}\text { To explain the } \\
M E M A \\
\text { kwaVijana trial } \\
\text { outcomes }\end{array}$ & Tanzania & $\begin{array}{l}\text { Community, } \\
\text { education and } \\
\text { healthcare } \\
\text { setting } \\
\text { (Rural area } \\
\text { communities, } \\
\text { primary } \\
\text { schools, health } \\
\text { facilities) }\end{array}$ & $\begin{array}{l}\text { Qualitative } \\
\text { ethnography study } \\
\text { design }\end{array}$ & $\begin{array}{l}\text { (92 trial } \\
\text { participants, } 6 \\
\text { single sex groups } \\
\text { of young } \\
\text { villagers) - aged } \\
\text { not specified, } 9 \\
\text { villages }\end{array}$ & $\begin{array}{l}\text { Participant } \\
\text { observation, in- } \\
\text { depth } \\
\text { interviews, } \\
\text { focus group } \\
\text { discussions, } \\
\text { stimulated } \\
\text { patient visits, } \\
\text { internal } \\
\text { monitoring and } \\
\text { evaluation, } \\
\text { annual surveys } \\
\text { of } \\
\text { implementers }\end{array}$ & $\begin{array}{l}\text { Thematic analysis } \\
\text { NUD*IST }\end{array}$ \\
\hline
\end{tabular}


Table 2

Identified barriers and facilitators to HIV prevention interventions for reducing risky sexual behavior among youth across the five Determinant Framework domains or levels [17]

Page 14/18 


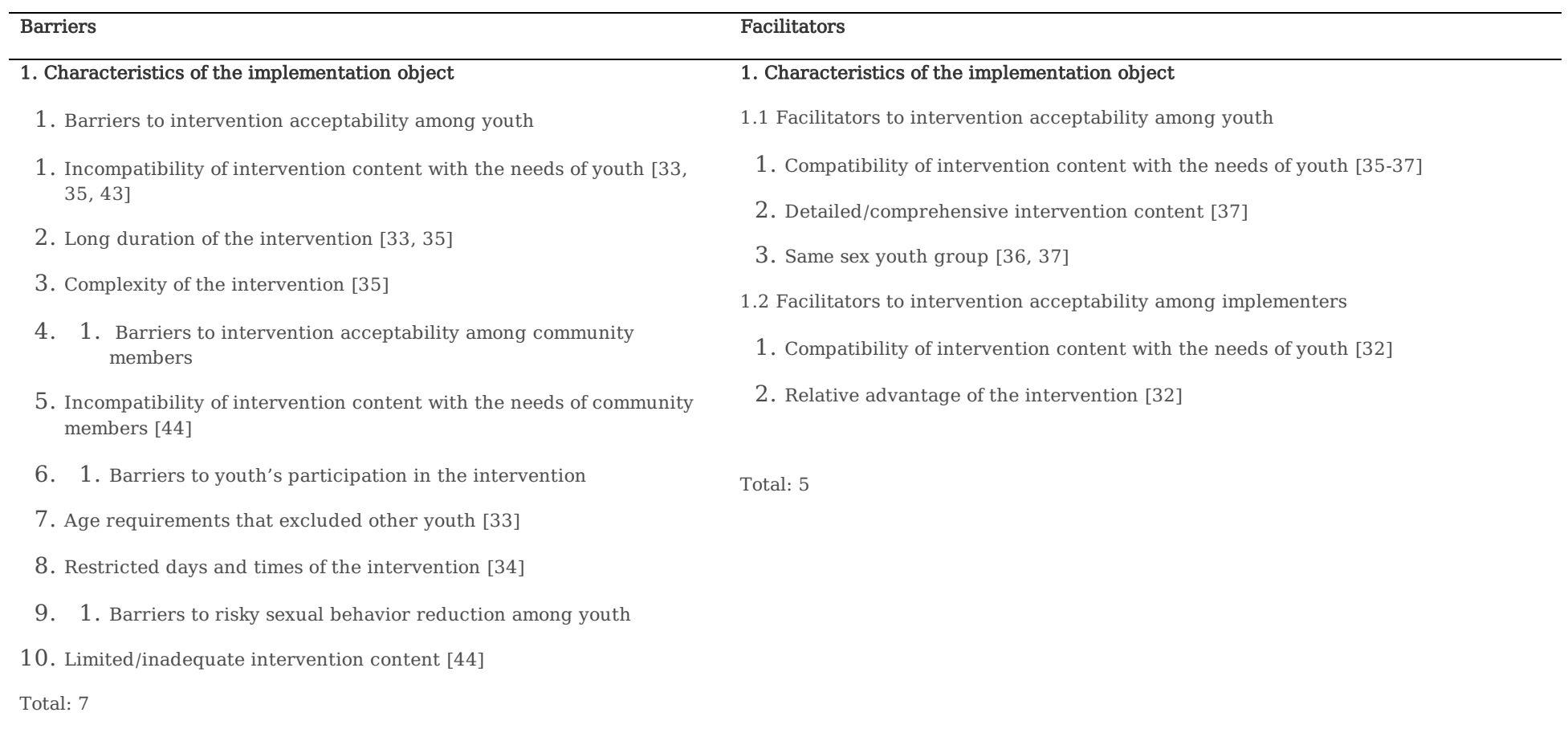

\section{Characteristics of the users/adopters}

1. Barriers to intervention success

1. Implementers' lack of knowledge related to intervention content [44]

2. Poor education or training of implementers [44]

3. Implementers' lack of exemplary or positive behavior [44]

4. 1. Barriers to intervention acceptability among youth

5. Adult/old implementers [37]

\section{Characteristics of the users/adopters}

2.1 Facilitators to intervention success

1. Training of implementers [32]

2. Knowledge of implementers [44]

2.2 Facilitators to intervention acceptability among youth

1. Experience of implementers [37]

2. Approachability/friendliness of implementers [33, 37]

Total: 4

\section{Characteristics of the end users}

3.1 Barriers to intervention success

1. Being uncooperative [44]

2. Low literacy [44]

3. Limited sexual health knowledge [44]

3.2 Barriers to risky sexual behavior reduction among youth

1. Negative attitudes towards condom use among young female sex workers [32]

2. Poor decision-making skills $[42,44]$

3. Lack of self-confidence [42]

4. Concern for privacy [33]

5. Fear of relationship breakdown [33, 38, 42, 43]

6. Fear of side effects of contraceptives [44]

7. Low perceptions of risk of sexually transmitted infections including HIV [38, 42-44]

8. Having higher sensation seeking [41]

9. Desire for pregnancy/children $[42,43]$

10. Being under the influence of alcohol/drugs [42]

11. Being stubborn/hard hardheaded [42, 43, 44]

12. Belief that one is incapable of change [42-44]

\section{Characteristics of the end users}

3.1 Facilitators to risky sexual behavior reduction among youth

1. Being knowledgeable [42]

2. Having good problem-solving skills [42]

3. Having high self-confidence [42]

4. Intentions/readiness to change [36]

5. Negative personal experiences in a relationship [39]

6. Fear of pregnancy and sexually transmitted infections including HIV [32, 37, 43]

7. Being self-reliant [39]

8. Having high self-motivation [39]

9. Having high self-respect [42]

10. Having high self-confidence [42]

11. Having high sense of responsibility [42]

12. Having strong ambitions/being future oriented $[39,44]$

13. Low socio-economic status (e.g., lack of money to pay for sex) [44]

3.2 Facilitators to youth's participation in the intervention

1. Desire to acquire knowledge [37]

2. Need for enjoyment [37] 
13. Being reliant on avoidance strategies [42]

14. Being unprepared [42]

15. Personal preferences [43]

16. Negative personal experiences with contraceptives [43]

Total: 15

3.3 Barriers to youth's participation in the intervention

1. Concern for privacy $[32,44]$

2. Fear of stigma [44]

Total: 21

\section{Characteristics of the context}

4.1 Interpersona

4.1.1 Barriers to intervention success

1. Lack of support for critical thinking among youth [44]

4.1.2 Barriers to risky sexual behavior reduction among youth

1. Partner refusal of an HIV prevention method (e.g., condom use, HIV testing $[32,33,38,39,42]$

2. Parent refusal of an HIV prevention method (e.g., HIV testing [32]

3. Lack of child-parent communication on sexual issues [36, 38]

4. Violent partner $[36,41]$

5. Partner's lack of condom-related knowledge [38]

6. Poor role models [38]

7. Lack of restrictive parenting [38]

8. Negative peer influence $[38,43,44]$

9. Lack of financial support from the family [38, 39, 43]

10. Relationship issues (e.g., current boyfriend and unstable relationships) $[41,42]$

11. Controlling partner $[42,43]$

12. Male partner suspect fidelity if a female partner request protected sex $[42)$

13. Partner's desire for pregnancy [42]

14. Partner is under the influence of drugs [42]

4.2 Community

4.2.1 Barriers to risky sexual behavior reduction among youth

1. Myths about contraceptives [32, 44]

2. Norms discouraging open communication on sexual issues $[32,44]$

3. Gender-biased norms [36-39, 43, 44]

4. Norms encouraging risky sexual behavior (e.g., transactional sex and unprotected sex) [44]

5. Cultural beliefs [44]

6. Limited resources/services in the community (e.g. programs for youth, condoms $[32,33]$

4.2.2 Barriers to youth's participation in the intervention

1. Violence in the community/neighborhood [34]

2. Incarceration [34]

4.3 Organizational or institutional

4.3.1 Barriers to intervention success

1. Limited resources (e.g., financial and human resources) [44]

2. Restrictions on depicting of condoms in schools [44]

\section{Characteristics of the context}

4.1 Interpersonal

4.1.1 Facilitators to risky sexual behavior reduction among youth

1. Restrictive parenting $[38,44]$

2. Positive peer influence [38, 44]

3. Teacher advice [38]

4. Parental advice [39]

5. Financial support from family $[39,43]$

6. Partner's preferences []

7. Parental/family support $[39,44]$

8. Stable relationships [42]

9. Partner's consent to of an HIV prevention method (e.g., condom use [42, 43]

10. Male partner does not suspect fidelity if a female partner request protected sex [42]

11. Family/parental religious beliefs (e.g., raised in a family with religious beliefs against risky sexual behavior [44]

4.2 Community

4.2.1 Facilitators to risky sexual behavior reduction among youth

1. Norms encouraging healthy sexual behavior (e.g., abstinence and delaying of sexual debut) $[38,44]$

2. Norms encouraging discussion of sexual issues [44]

3. Religious beliefs discouraging risky sexual behavior [38]

4.3 Organizational or institutional

4.3.1 Facilitators to intervention acceptability among youth

1. Accessibility and friendliness of the intervention venue [33] 
3. Inaccessibility of services (e.g., health centers [44]

4. Limited confidentiality [44]

4.3.2 Barriers to risky sexual behavior reduction among youth

1. Limited resources (e.g., condoms, staff shortages) [44]

2. Inaccessibility of services (e.g., condoms, heath centers) [44]

3. Limited confidentiality [44]

4.3.3 Barriers to youth's participation in the intervention

1. Inaccessibility of intervention venue [34, 37]

4.4 Structural

4.4.1 Barriers to intervention success

1. Poverty [44]

2. Limited demand for services (e.g., condoms) [44]

3. Cost of services (e.g., condoms) [44]

4.4.2 Barriers to risky sexual behavior reduction among youth

1. Poverty $[32,44]$

2. Unemployment [32]

3. Limited economic opportunities [44]

4. Women's subordinate status [44]

5. Cost of services (e.g. secondary education) $[39,44]$

6. Inaccessibility of services (e.g. schools) [39]

7. Gender-based violence $[39,41]$

8. Economic constrains [43]

Total: 42

\section{Characteristics of the strategy or other means of facilitating 5. Characteristics of the strategy or other means of facilitating implementation} implementation

\section{Barriers to intervention success}

1. Failure to implement the intervention with fidelity [44]

2. Use of non-participatory teaching/facilitating methods [44]

3. Use of corporal punishment [44]

4. Sexual abuse [44]

5.2. Barriers to intervention acceptability among youth

1. Use of non-participatory facilitating methods) [32]
5.1 Facilitators to intervention success

1. - Implementation of intervention with fidelity $[40,44]$

2. - Use of participatory facilitating methods [44]

3. - Decreased corporal punishment [44]

4. Dissemination of intervention information to community members [32, 36, 37]

5. Collaboration among different stakeholders in delivering the intervention [32]

5.2 Facilitators to youth's participation in interventions

1. Mobilization of community members to influence youth to attend the intervention [32]

2. Integration of intervention with other services [32]

3. Provision of detailed intervention information to parents [32]

4. Using outreach activities [32]

5. Building of a trusting relationship with young people [32]

6. Use of same age or peer implementers [32]

7. Provision of incentives [32, 37]

5.3 Facilitators to intervention acceptability among youth

1. Use of different or mixed facilitating methods [35]

2. Use of same sex youth group [36, 35]

Total: 14 


\section{Figures}

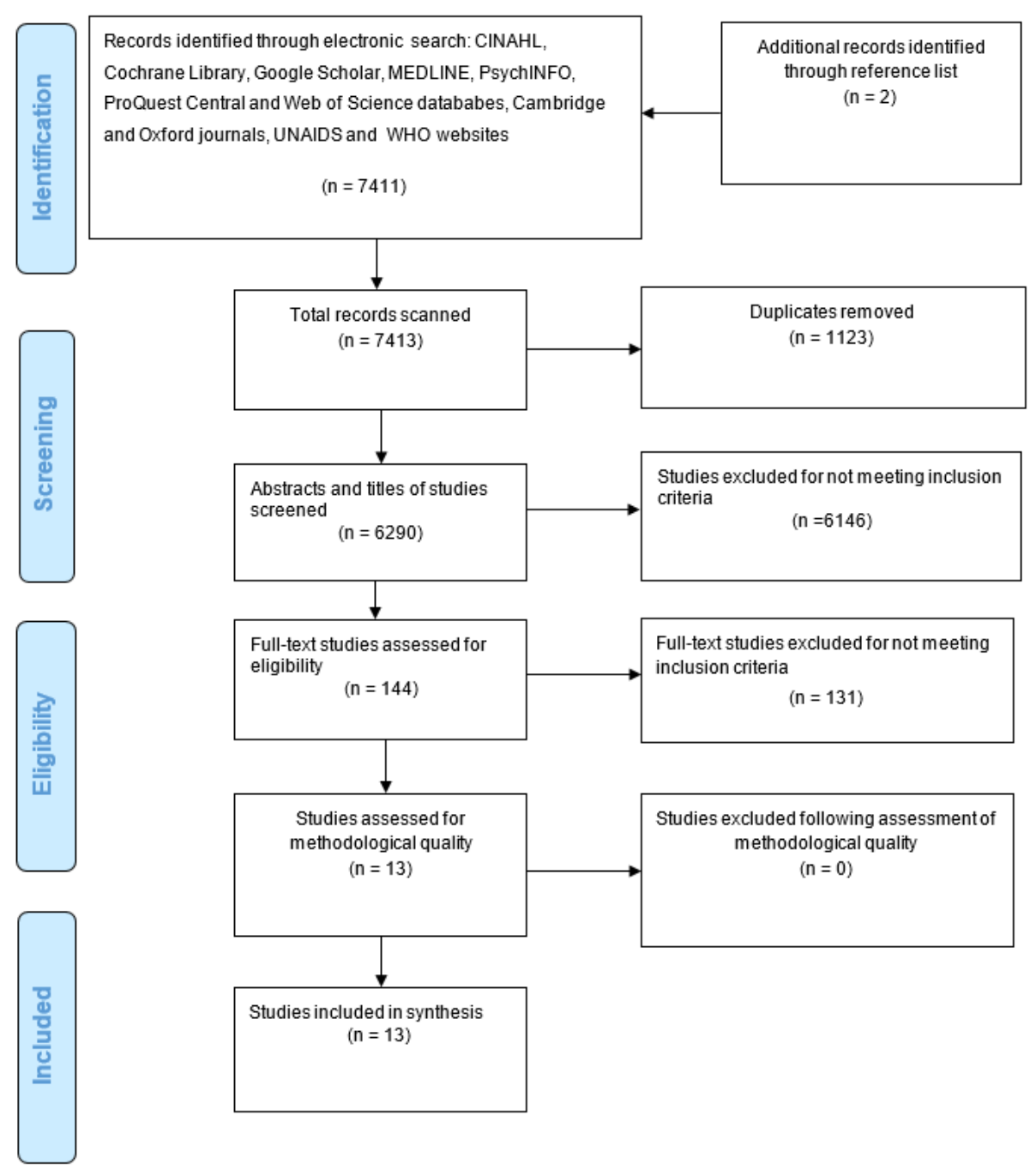

Figure 1

PRISMA flow diagram illustrating selection of studies examining barriers and facilitators to HIV prevention interventions for reducing risky sexual behavior among youth

\section{Supplementary Files}

This is a list of supplementary files associated with this preprint. Click to download.

- Supplementaryfile1.docx

- SupplementaryFile2.docx

- PRISMAChecklist.docx 